ORIGINAL ARTICLE

\title{
Development of Solar Assisted Multi-Crop Dryer
}

\section{G.M.A.S. Galappaththi ${ }^{1}$, G. V.T. V. Weerasooriya ${ }^{1 *}$, A.J. Fernando ${ }^{1}$ and D.P. Senanayaka ${ }^{2}$}

\author{
${ }^{1}$ Department of Agricultural \\ Engineering and Soil Science, \\ Faculty of Agriculture, Rajarata \\ University of Sri Lanka, \\ Anuradhapura \\ (50000), Sri Lanka. \\ ${ }^{2}$ National Institute of Post- \\ Harvest Management, Research \\ \& Development Centre, \\ Jayanthi Mawatha, \\ Anuradhapura (50000), Sri \\ Lanka.
}

\section{Correspondence:}

*gvtvw@agri.rjt.ac.lk

(D) https://orcid.org/0000-0001-8911-7675

DOI: http://doi.org/10.4038/sljae.v3i1.58

\begin{abstract}
Appropriate technology for the conversion of solar radiation to thermal energy is vital for food dehydration. Solar drying considered an advancement of sundrying is an efficient solar energy system. A reliable and low-cost multi-crop solar drying technique is required for small scale farmers in Sri Lanka. Therefore, the objective of this study was to develop a solar heater assisted multi-crop dryer for small scale farmers. The main components of solar dryer are flat plate solar collector, drying chamber, solar panel with air DC heater, turbo ventilator, exhaust fans, and temperature control system. The performance of the fabricated solar assisted multi-crop dryer with DC air heater was evaluated for drying rate and drying efficiency of three agro-products; bitter gourd (Momordica charantia), jackfruit (Artocarpus heterophyllus) and mushroom (Pleurotus ostreatus). The drying rates were $0.151 \mathrm{kgh}^{-1}$ for bitter gourd, $0.145 \mathrm{kgh}^{-1}$ for jackfruit, and $0.154 \mathrm{kgh}^{-1}$ for mushroom. The efficiency of solar collector was $25.84 \%$. The drying efficiencies for bitter gourd, jackfruit, and mushroom were $12.85 \%, 12.35 \%$, and $13.15 \%$, respectively. Further, favorable colour could be achieved by the modified solar assisted multi crop dryer. Therefore, the solar assisted multi-crop dryer designed in the present experiment is an effective method of converting solar radiation to thermal energy and could be recommended for small scale farmers in Sri Lanka for drying agro products. Further improvements are required to increase solar thermal efficiency.

Keywords: Drying efficiency, Drying rates, Hot-air drying, Multi-crop dryer, Solar drying
\end{abstract}




\section{Introduction}

Drying of agricultural produce decreases the moisture content and increases the shelf-life of the product (Eltief et al. 2007). Sun-drying of agricultural produce is the traditional method practiced in developing countries. The agricultural produce is directly exposed to solar radiation in sun-drying, and the moisture is removed by the convective power of the natural wind. Although sun-drying is a cheap method of drying, it has inherent disadvantages. Sundrying depends on weather conditions and highly vulnerable to the attack of dust, dirt, rain, insects, pests, and microorganisms (Raju et al. 2013). Solar drying is an alternative to sundrying, which offers several advantages over the traditional sun-drying.

Solar energy for crop drying is environmentally friendly and economically viable in developing countries. The solar dryers have higher drying temperatures in the drying chamber resulting higher drying rates. The food is enclosed in the solar dryer and therefore, protected from dust, insects, birds, and animals. The faster drying rates in solar dryers reduces the risk of spoilage by microorganisms, and provides a higher throughput. The solar dryers are constructed from locally available materials and are relatively of low cost. However, the limitations of solar dryers are that those dryers can only be used during daytime when an adequate amount of solar energy is present, lack of skilled personnel for operation, and maintenance (Tiwari 2016).
However, there is a significant potential of solar dryers in the agricultural sector to dry grains, vegetables, fruits, and medicinal plants while saving quality of the product. Solar drying under a controlled weather condition reduces the products' moisture level to a safe limit and ensures product quality (Agrawal and Sarviya, 2014).

Continuous drying is essential to improve the quality of dried products. A backup heating system is necessary for continuous drying of agricultural products (Tiwari 2016). Therefore, a continuous backup heating would be advantageous for increasing the drying efficiency of a solar assisted dryers. Further, a temperature control mechanism in the dryer would enhance the drying process and products' efficiency and quality. Although, several solar dryers are available at present, a high-efficiency multi-crop hot-air solar dryer with a temperature control mechanism is not available for small-scale farmers in Sri Lanka. Therefore, the objective of this study was to design and develop an efficient Solar-assisted Multi-Crop Dryer (SAMD) with a temperature control mechanism.

\section{Materials and Method}

An indirect type solar dryer was designed, developed, and fabricated to increase the solar drying efficiency of agricultural products. This study was carried out at the Engineering workshop, National Institute of Post-Harvest Management (NIPHM), Jayanthi Mawatha, Anuradhapura (Latitude $8^{0} 19^{\prime} 12^{\prime \prime} \mathrm{N}$, Longitude $80^{\circ} 23^{\prime} 33^{\prime \prime} \mathrm{E}$, and the average solar irradiation 
$6.72 \mathrm{kWhm}^{-2}$ day $^{-1}$ (Watts 2019)). The ambient temperature and the relative humidity during the experimental time were $33.49 \pm 5^{\circ} \mathrm{C}$ and $52.67 \pm 4 \%$.

The drying temperature was regulated in the drying chamber to improve the quality of dried products. Fresh bitter gourd (Momordica charantia), jackfruit (Artocarpus heterophyllus) and mushroom (Pleurotus ostreatus) were used to evaluate the SAMD.

\section{Design Criteria}

Different design criteria and parameters were considered while developing the SAMD. The drying temperature and drying chamber capacity were determined according to the literature as described below. The calculated design parameters for SAMD were, the amount of moisture to be removed, heat energy required to remove water, the collector's size, collector orientation, tilt angle, and airflow requirement.

\section{Drying Temperature}

Drying temperatures for fruits and vegetables are $45^{\circ} \mathrm{C}-60^{\circ} \mathrm{C}$. Higher temperatures reduce the quality of the final product (Agrawal and Sarviya, 2014). Therefore, the optimum temperature for SAMD was selected as $55^{\circ} \mathrm{C}$. Microcontroller based temperature control system was developed to regulate the temperature in the drying chamber of SAMD.

\section{Dryer Capacity}

The dryer capacity for SAMD was determined as $3 \mathrm{~kg}$. The SAMD was designed with three perforated trays, to hold $3 \mathrm{~kg}$ of products.

\section{Amount of Moisture to be Removed}

Equation 1 was used to calculate the total amount of moisture to be removed (Hernandez et al. 2000).

$$
M w=\frac{W_{w}\left(M_{i}-M_{f}\right)}{1-M_{f}}
$$

Where: $\mathrm{M}_{\mathrm{w}}=$ Total amount of moisture removed, $\mathrm{kg}$

$\mathrm{W}_{\mathrm{w}}=$ Initial total weight, $\mathrm{kg}$

$\mathrm{M}_{\mathrm{i}}=$ Initial moisture content on wet basis, \%

$\mathrm{M}_{\mathrm{f}}=$ Final moisture content on wet basis, \%

\section{Heat Energy Required to Remove Moisture}

The heat energy required to remove water from a product was calculated by the equation 02 proposed by Mercer (2007). The formula considered drying as a two-stage process; the first stage was raising the wet material's temperature to the desired level at which the moisture was removed (includes sensible heat).

The second stage of Mercer (2007) formula was evaporating the moisture from the product. As the water started to evaporate after the product was heated up to the drying temperature, the heat required to evaporate moisture was given by equation 3 (includes latent heat of vaporization). 
$Q_{1}=W_{W} \times C_{p} \times T$

Where; Q= Required Heat Energy, kJ

$\mathrm{C}_{\mathrm{p}}=$ Specific heat capacity of the produce, $\mathrm{kJ} \mathrm{kg-}$ ${ }^{10} \mathrm{C}^{-1}$

$\mathrm{T}=$ Temperature change, ${ }^{0} \mathrm{C}$

$\mathrm{W}_{\mathrm{w}}=$ Initial total weight, $\mathrm{kg}$

$\mathrm{C}_{\mathrm{p}}=3.35 \mathrm{~kJ} \mathrm{~kg}^{-1}{ }^{0} \mathrm{C}^{-1}$

$Q_{2}=M_{w} \times L$

Where, $\mathrm{L}=$ Latent heat of vaporization, $\mathrm{kJ}$

$\mathrm{M}_{\mathrm{w}}=$ Amount of moisture removed, $\mathrm{kg}$

Accordingly, the total heat requirement for drying product was the summation of $\mathrm{Q}_{1}$ and $\mathrm{Q}_{2}$. The total energy supply for SAMD needed to be higher than the amount of energy required to remove the moisture from the product due to the energy losses to the environment through the SAMD.

\section{Sizing the Collector}

The collector efficiency is influenced by temperature, airflow rate, insolation, type of transparent materials, absorber plate, and insulation. According to Struckmann (2008), a typical flat-plate efficiency (at ambient temperature $25^{\circ} \mathrm{C}$ and $\mathrm{I}=400 \mathrm{Wm}^{-2}$ ) is between $25 \%$ and $45 \%$. Therefore, the collector efficiency of $35 \%$ was selected as a parameter to achieve an optimal design.

Daily expected energy production by the collector was $8467.2 \mathrm{kJm}^{-2}$ day $^{-1}$. Since the total heat energy required for drying was $5.8912 \mathrm{MJ}$, the collector area was $0.696 \mathrm{~m}^{2}$. Although the collector area was approximated to $0.70 \mathrm{~m}^{2}$, considering the heat losses to the environment, the collector area was determined as $1 \mathrm{~m}^{2}$. Forson et al. (2007) suggested the length to width ratio of a solar collector to be 1:3. Therefore, the length, and width of the collector was selected as $1.7 \mathrm{~m}$ and $0.6 \mathrm{~m}$, respectively. A corrugated sheet was used to increase the effective surface area and the surface was painted with black to minimize heat loss from the absorber plate. The bottom of the collector was filled with metal.

\section{Collector Orientation and Tilt Angle}

The flat plate solar collector should be tilted and oriented in a way that the plate receives maximum radiation. The optimal tilt angle varies according to the season. As a general rule, optimum solar collector tilt angel for the summer region is latitude $+19^{\circ}$ (Weiss and Buchinger 2002). The NIPHM located at $8^{0} 19^{\prime}$ $12^{\prime \prime} \mathrm{N}$ and $80^{\circ} 23^{\prime} 33^{\prime \prime} \mathrm{E}$, therefore, the collector tilt angle of $27^{\circ}$ was considered for the SAMD design. This avoided rainwater accumulation on the collector during rainy periods and facilitated the natural convectional flow.

\section{Airflow Requirement}

Scanlin (1997) recommended the range of air velocity between $0.51 \mathrm{~ms}^{-1}$ to $5.08 \mathrm{~ms}^{-1}$ and the depth of the air channel should be $1 / 15$ to $1 / 20$ of the length of the collector. $10 \mathrm{~cm}$ was considered as the depth of the air channel for the solar collector. Therefore, the calculated vent area was $0.06 \mathrm{~m}^{2}$ (Equation 4). The airflow 
rate was $0.0306 \mathrm{~m}^{3} \mathrm{~s}^{-1}$ for $0.51 \mathrm{~ms}^{-1}$ (Equation $5)$.

\section{Vent area $=$ width of collector $\times$ air gap}

Airflow rate $=$ vent area $\times$ air velocity

The mass flow rate $\left(0.037 \mathrm{kgs}^{-1}\right)$ was determined by multiplying the volume flow rate by the density of air, $1.2 \mathrm{kgm}^{-3}$. This mass flow rate value lies between the range of $0.02-0.9$ $\mathrm{kgs}^{-1}$, as recommended by Forson et al. (2007) for natural convection dryers.

The size of dryer needed to dry a given weight of food per batch was calculated for different types of products using the assumptions provided by Saxena and Goel (2013). Area of 1 $\mathrm{m}^{2}$ can be used for $2 \mathrm{~kg}$ of less dense products, 4 $\mathrm{kg}$ of moderate dense products and $6 \mathrm{~kg}$ of chopped fruits. Since $1 \mathrm{~m}^{2}$ is needed for around $4 \mathrm{~kg}$ of products, $3 \mathrm{~kg}$ products require $0.75 \mathrm{~m}^{2}$. Since the number of trays for the SAMD dryer was 3 , the area of one tray was $0.25 \mathrm{~m}^{2}$.

The dimensions of one tray were $0.58 \mathrm{~m} \times 0.52$ $\mathrm{m}$. The gap between the two trays was $15 \mathrm{~cm}$, and the gap between the bottom plate to the tray was taken as $20 \mathrm{~cm}$. Therefore, dimensions of the drying chamber were determined as 0.64 $\mathrm{cm} \times 0.60 \mathrm{~cm} \times 0.56 \mathrm{~cm}$.

\section{Experimental Procedures for Dryer Evaluation}

\section{Material Preparation}

Fresh bitter gourd, jackfruit, and mushroom were obtained from the local market. Fresh ripen bitter gourd were peeled and sliced. Matured unripe jack fruit bulbs were sliced, and seeds were removed. Mushroom tender parts were also sliced. According to Solar Flex (2013), approximate slice thickness of $3 \mathrm{~mm}$ for drying of bitter gourd, jackfruit and mushroom were used. Hot water blanching pre-treatments was carried for jackfruit and bitter gourd slices. Fresh produce was placed on a single layer to avoid moisture being trapped in to lower tray.

\section{Instruments Used for Data Collection}

The parameters measured during testing and evaluation of SAMD included the materials' initial weight, temperature, humidity, and solar insolation. The drying chamber, solar heat collector inlet, and the chimney outlet temperature and relative humidity were measured using thermocouples (T-type) and Humidity Temperature meter (Model: TECPEL 322). The moisture content of products was measured by moisture meter (Model: MS 25). Further, meteorological data were obtained from the meteorological station at Faculty of Agriculture, Rajarata University of Sri Lanka.

\section{Testing and Evaluation of the Dryer}

Testing and evaluation of the dryer before and after installing the DC air heater were carried under no-load and loaded conditions. Further, the open sun-drying data for each product were collected. The temperature and relative humidity were measured in every 30 minutes at the top tray and bottom tray of the drying chamber, at the inlet and outlet of the collector, and in the ambient environment. 
The open sun-drying tests were conducted as a control test. The products were placed on trays and the ambient temperature and humidity, and product moisture content were recorded every 30 minutes.

The temperature and relative humidity data were collected without loading the product in the drying chamber. Then the loaded tests of the SAMD before and after installing the DC air heater were carried out for bitter gourd, jack fruit, and mushroom. The product slices were placed as a single layer on each tray to ensure uniform drying. The moisture content wet basis was measured every 30 minutes.

\section{Efficiency Calculations of SAMD}

\section{Thermal Efficiency of the Solar Heat Collector}

Overall thermal performance of solar heat collector was calculated using the equation 6 (Struckmann 2008).

$$
\eta_{C}=\frac{v \rho \Delta T C_{P}}{I_{C} A_{C}} \times 100
$$

Where, $\mathrm{v}=$ Volumetric flow rate of air, $\mathrm{kgm}^{-3}$

? = Air density, $\mathrm{kgm}^{-3}$

$\Delta \mathrm{T}=$ Air temperature elevation, ${ }^{0} \mathrm{C}$

$\mathrm{C}_{\mathrm{p}}=$ Air specific heat capacity, $\mathrm{Jkg}^{-1}{ }^{0} \mathrm{C}^{-1}$

$\mathrm{I}_{\mathrm{c}}=$ Insolation on collector surface, $\mathrm{Wm}^{2}$

$\mathrm{A}_{\mathrm{c}}=$ Collector area, $\mathrm{m}^{2}$

\section{Solar Dryer Efficiency}

Efficiency of the SAMD was calculated using equation 7 (Leon et al. 2002).

$$
M R=\frac{M_{w}}{t}
$$

Where, $\eta_{\mathrm{s}}=$ Drying efficiency of dryer, $\%$ $\mathrm{w}=$ Weight of water removed, $\mathrm{kg}$ $\mathrm{L}=$ Latent heat of vaporization of water, $\mathrm{Jkg}^{-1}$ $\mathrm{A}=$ Area of the solar collector, $\mathrm{m}^{2}$ $\mathrm{I}=$ Solar irradiation, $\mathrm{Jm}^{-2}$

\section{Drying Rates}

The drying rate of the dryer was calculated using the equation 8 (Hernandez et al. 2000).

$$
M R=\frac{M_{w}}{t}
$$

Where,

$\mathrm{MR}=$ Moisture removal rate, $\mathrm{kgs}^{-1}$

$\mathrm{M}_{\mathrm{w}}=$ Amount of moisture removed from $1 \mathrm{~kg}$ of product, $\mathrm{kg}$

$\mathrm{t}=$ Drying time, $\mathrm{s}$

\section{Statistical Analysis}

Each drying experiment was conducted in three replicates. Collected data were represented using descriptive statistics. The significance of the treatments was tested by using analysis of variance (ANOVA) procedure using SAS 9.0 software. Least square difference (LSD) was used to separate the means of significant variables at $0.05(\alpha)$ level.

\section{Results and Discussion}

The SAMD was fabricated and tested for different crops. The dimensions of the components of the SAMD were given in Table 1. 


\section{Solar Heat Collector}

The energy from sun was collected by a solar collector and transferred to the drying air in the drying chamber. The dimensions of solar collector were $1.7 \mathrm{~m} \times 0.6 \mathrm{~m}$ of length and width, respectively. The three major components of solar collector were glass top, absorber plate, and insulation.

Table 1. Dimensions of the components of the SAMD

\begin{tabular}{lll}
\hline Components & Description & Dimension \\
\hline Capacity & $3 \mathrm{~kg}$ & \\
\hline \multirow{2}{*}{ Solar } & Length & $1.70 \mathrm{~m}$ \\
collector & Width & $0.60 \mathrm{~m}$ \\
& Height & $0.10 \mathrm{~m}$ \\
& Tilt angle & $27^{0}$ \\
\hline \multirow{4}{*}{ Tray } & Length & $0.58 \mathrm{~m}$ \\
& Width & $0.52 \mathrm{~m}$ \\
& Mesh area & $0.01 \mathrm{~m}$ \\
& Between trays & $0.15 \mathrm{~m}$ \\
& Between bottom & $0.20 \mathrm{~m}$ \\
Drying & plate and tray & \\
chamber & Length & $0.64 \mathrm{~m}$ \\
& Width & $0.60 \mathrm{~m}$ \\
& Height & $0.56 \mathrm{~m}$ \\
\hline \multirow{2}{*}{ Solar panel } & Length & $1.50 \mathrm{~m}$ \\
& Width & $1.00 \mathrm{~m}$ \\
& Tilt angle & $27^{0}$ \\
\hline \multirow{5}{*}{ DC air heater } & Width & $0.40 \mathrm{~m}$ \\
& Height & $0.08 \mathrm{~m}$ \\
& & $0.10 \mathrm{~m}$ \\
& &
\end{tabular}

The glass top was made from single layer glass of $5 \mathrm{~mm}$ thickness. The collector basin was filled by the heat-absorbing materials, metal (black stones) average size $30 \mathrm{~mm}$. Black painted corrugated aluminum sheet of $2 \mathrm{~mm}$ thickness was used as an absorber. Aluminum sheets sheeted on the top of the metal layer and two opposite sides of the collector. The collector casing was made from iron sheet. Rigifoam sheet with thickness of $3 \mathrm{~mm}$ was placed underneath and sides of the collector to minimize heat loss from the collector. When the atmospheric air passes through the collector, the air gets heated before entering the drying chamber. The air inlet opening was on the bottom of the black painted corrugated aluminum sheet and upper opening connected to the drying chamber to continue the air-flow. Tibebu (2015) recommended to use silicone glue to avoid heat losses from the solar heat collector. The air inlet fixed on $30 \mathrm{~cm}$ height from the floor to avoid entering of dust. The gap between the glass cover and absorber plate was $5-8 \mathrm{~cm}$ as recommended by Tibebu (2015) to increase the collector efficiency. It Also avoids entering low-temperature air to the drying chamber.

\section{Drying Chamber}

Drying chamber $(64 \mathrm{~cm} \times 60 \mathrm{~cm} \times 53 \mathrm{~cm})$ was made from iron sheets with L-iron support. Three trays were developed from plastic-coated metal mesh $\left(1 \times 1 \mathrm{~cm}^{2}\right)$ to hold $3 \mathrm{~kg}$ of product. The plastic-coated mesh was chosen to avoid rusting due to the high initial moisture content and the acidic nature of the products. A circular hole of $10 \mathrm{~cm}$ diameter was made on drying chamber as the turbo ventilator outlet. A door was made for loading and unloading of the products. The drying chamber receives heated air from the solar heat collector. The mat foil 
insulation reduced the heat losses from the drying chamber.

\section{Air Distribution System}

Air distribution system was used for even distribution of heat energy and to remove moisture from the product. Air was circulated both horizontally and vertically through the trays in the drying chamber. The inlet fans and the turbo ventilator facilitated forced air convection. Inlet fans were powered by solar panel and the turbo ventilator was operated by wind energy and convection heat.

\section{Temperature Control System}

Microcontroller based temperature control system was developed to regulate the temperature of the drying chamber. Temperature sensors (LM-35) measured the top layer temperature as input data. The Arduino program monitored the temperature generated output signal and provided to the relay (SRD-05VDC). The relay was used to connect and disconnect the current supply for the DC air heater.

\section{Air Heater}

DC air heater, powered by the solar panel, provided heat to the drying chamber. The capacity of the heater was $450 \mathrm{~W}$. Microcontroller based temperature control system regulated the operation of the DC air heater.

\section{Fabricated SAMD}

The fabricated SAMD have shown in Plate 1 and 2.

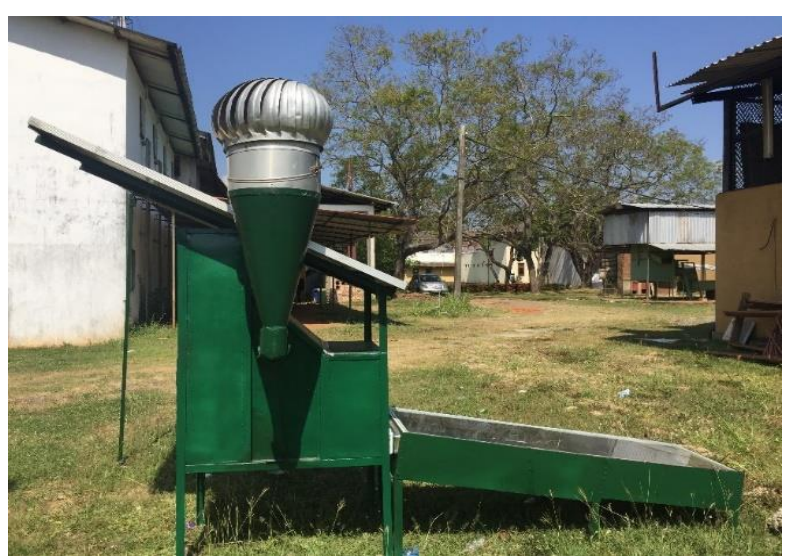

Plate 1. Side view of the solar-assisted multi-crop dryer

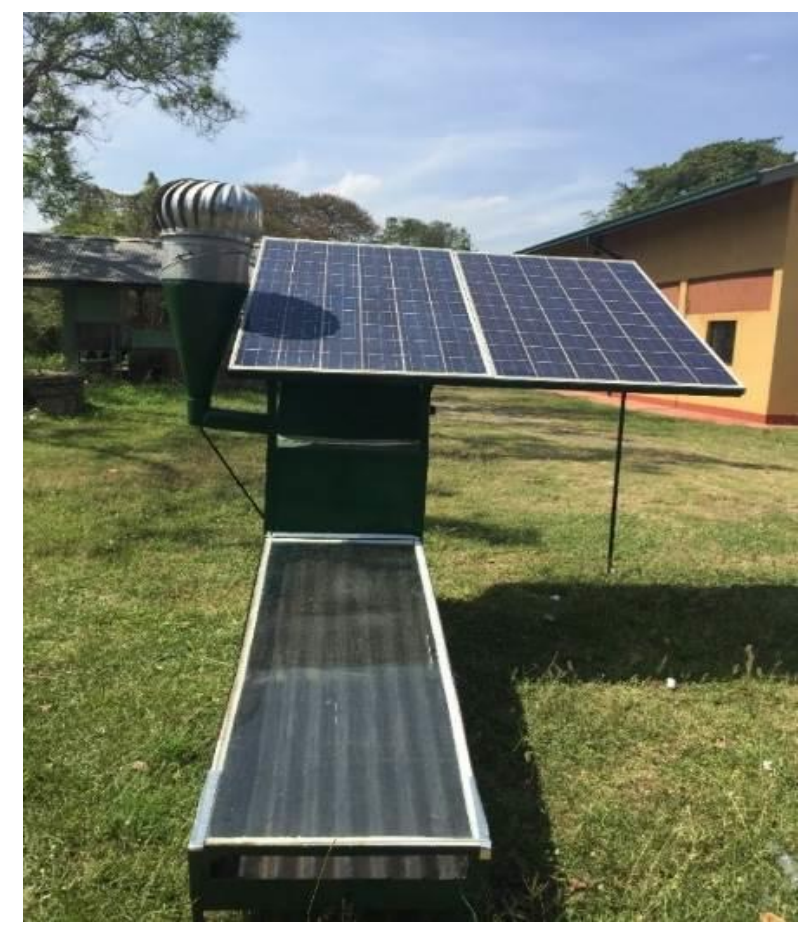

Plate 2. Front view of solar-assisted multi-crop dryer

\section{Testing of Solar-assisted Multi-Crop Dryer}

\section{No Load Test}

The temperature variation of ambient air and the drying chamber before and after installing the DC air heater during the no-load test is shown in Fig. 1 and 2. 


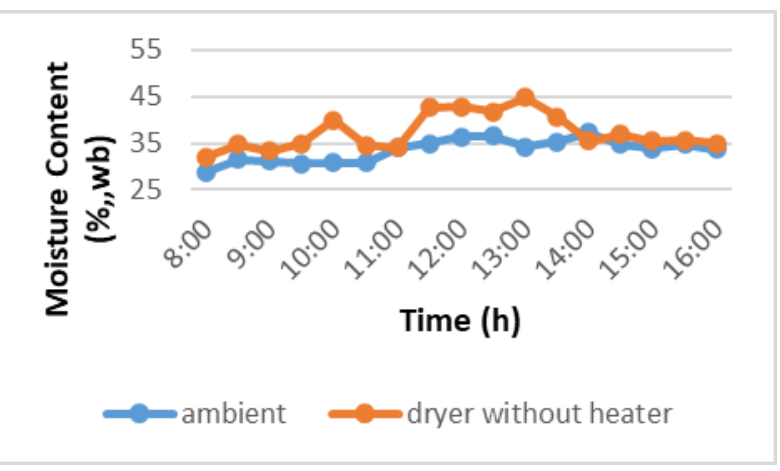

Figure 1. No load condition-before installing the heater

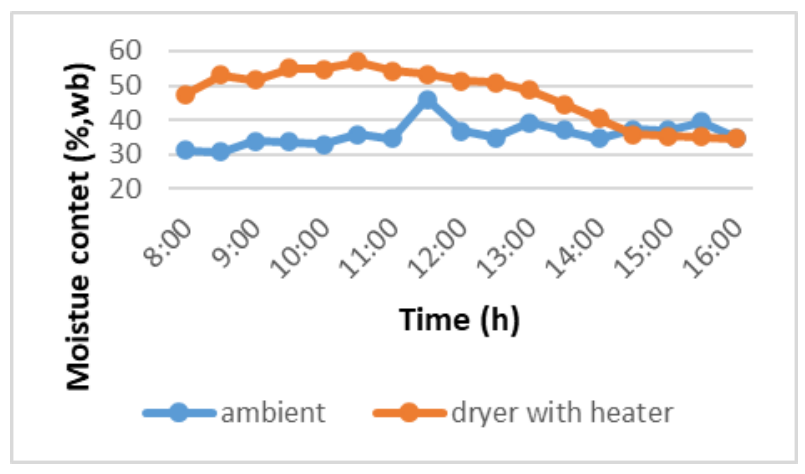

Figure 2. No load condition-after installing the heater

Before installing the DC air heater, the average temperature of $37.30 \pm 3.83^{\circ} \mathrm{C}$ (Max: $44.75^{\circ} \mathrm{C}$ ) was obtained by the drying chamber from 8:00 to $16: 00$ hour, with the average ambient temperature of $33.50 \pm 2.43^{\circ} \mathrm{C}$ (Max: $37.2^{\circ} \mathrm{C}$ ). After installing the DC air heater, the SAMD drying chamber achieved the average temperature of $47.23 \pm 7.98^{\circ} \mathrm{C}$ (Max: $56.86^{\circ} \mathrm{C}$ ) at same day time with the average ambient temperature of $35.85 \pm 3.60^{\circ} \mathrm{C}$ (Max: $46.10^{\circ} \mathrm{C}$ ). According to Mercer (2007), $55^{\circ} \mathrm{C}$ to $60^{\circ} \mathrm{C}$ is the optimum air temperature to dry food products and the air temperature should not exceed $60^{\circ} \mathrm{C}$ because higher temperature destroys nutrients and reduces the quality of the final product.

\section{Drying Curves}

The moisture content of bitter gourd jackfruit, and mushroom for 30 minutes of interval during three drying tests; sun-drying, SAMD before installing heater, and SAMD after installing the DC air heater were recorded in two consecutive days until product moisture content reached to the storage temperature. The moisture content variation with time for bitter gourd, jackfruit, and mushroom are shown in Fig. 3, 4, and 5, respectively. The moisture removal rate was increased during the day time for each agro-products due to higher temperature. Besides, SAMD with heater showed a significant higher moisture reduction in bitter gourd (Fig. 3). 


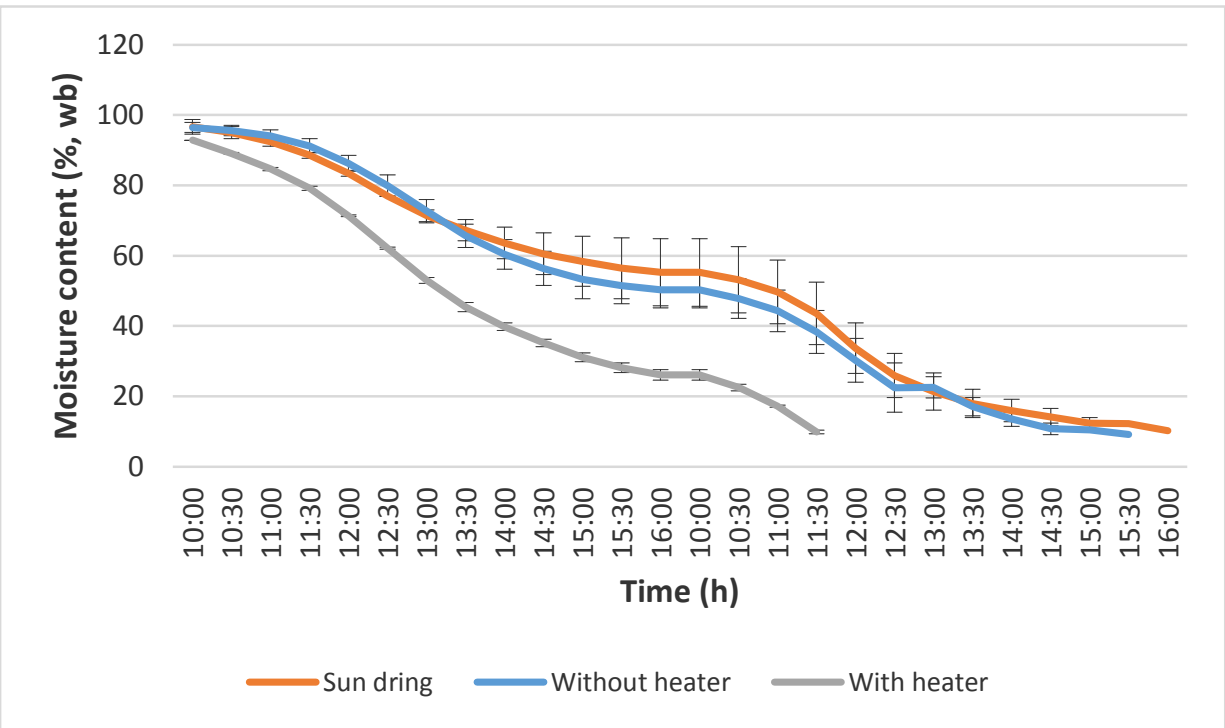

Figure 3. Drying curve for bitter gourd

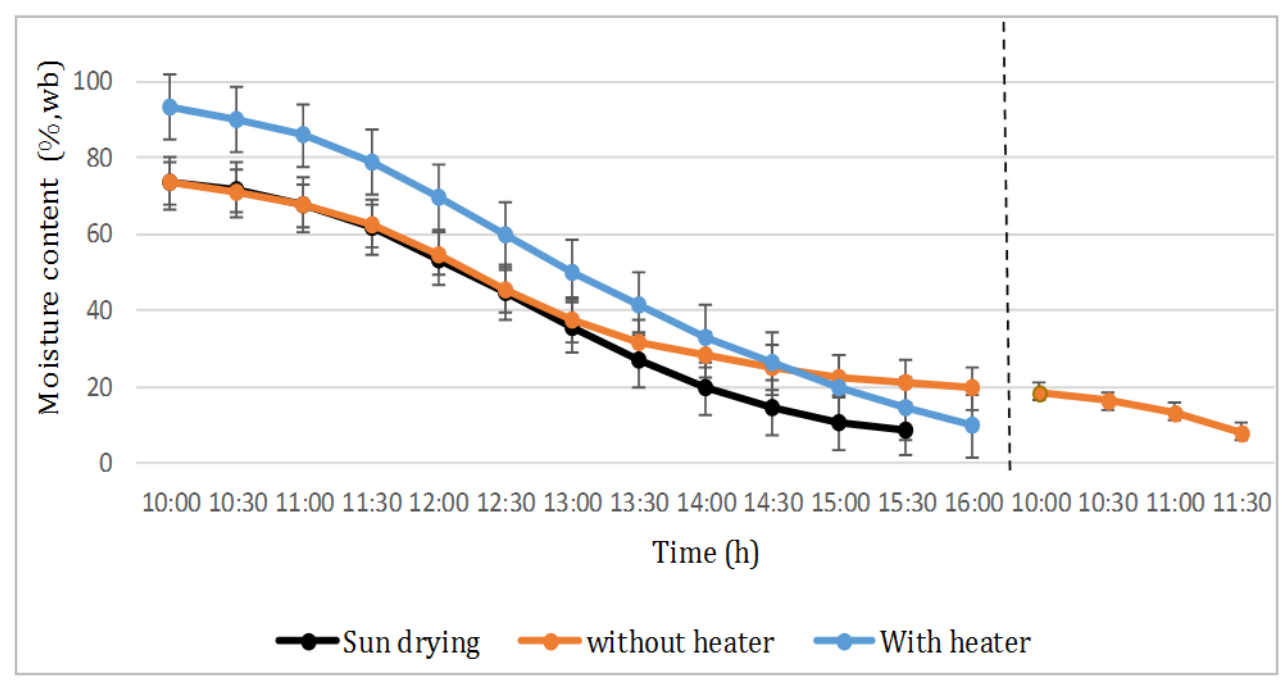

Figure 4. Drying curve for jackfruit

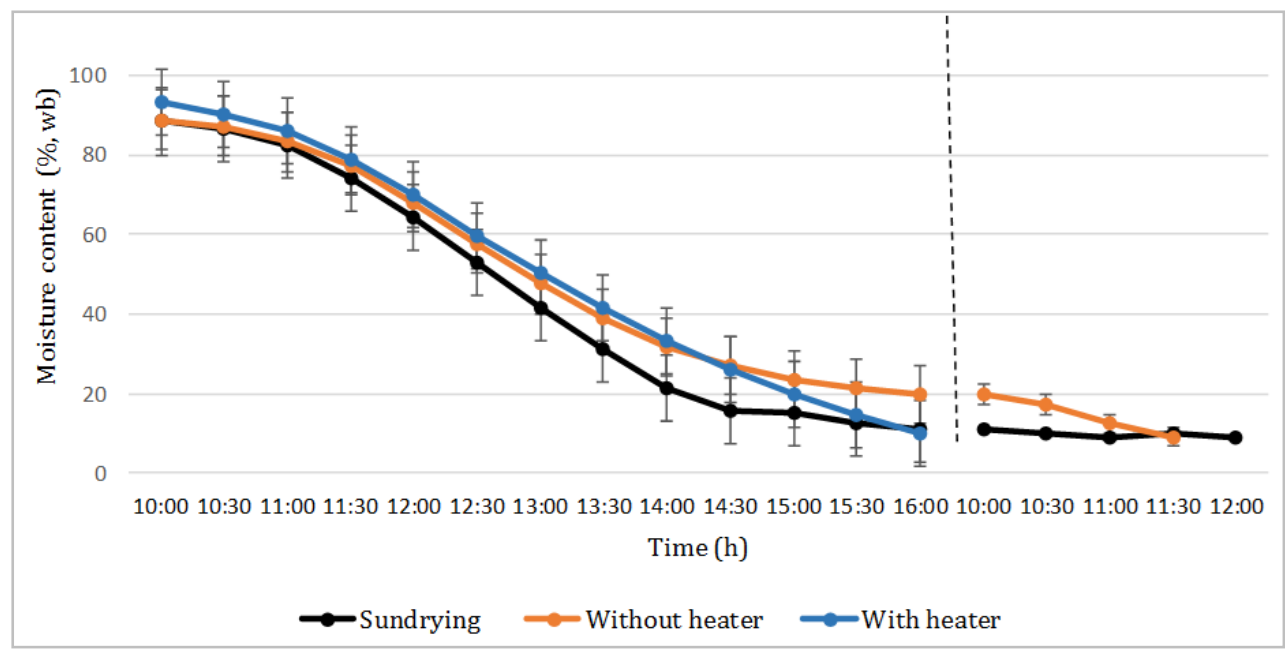

Figure 5. Drying curves for mushroom 


\section{Drying Rates}

The drying rate for each trial is presented in Table 2. The significantly highest drying rates for jackfruit were achieved by SAMD with DC air heater than solar drying and the SAMD without air heater respectively; because of the higher temperatures generated by the DC air heater in the drying chamber.

Table 2. Drying rates for different products

\begin{tabular}{lllr}
\hline \multirow{2}{*}{ Source } & \multicolumn{3}{c}{ Drying rates (kg/h) } \\
\cline { 2 - 4 } & $\begin{array}{l}\text { Bitter } \\
\text { gourd }\end{array}$ & Jackfruit & Mushroom \\
\hline $\mathrm{T}_{1}$ & 0.1203 & $0.1249^{\mathrm{b}}$ & 0.1309 \\
$\mathrm{~T}_{2}$ & 0.1061 & $0.0903^{\mathrm{c}}$ & 0.1326 \\
$\mathrm{~T}_{3}$ & 0.1506 & $0.1447^{\mathrm{a}}$ & 0.1541 \\
\hline
\end{tabular}

$T_{1}-$ Sun drying, $T_{2}-S A M D$ without $D C$ air heater, $T_{3}$ SAMD with DC air heater, *Significant difference at $p \leq 0.05$, Means in the same columns followed by different letters are significantly different at $p \leq 0.05$ according to $L S D$.

\section{Thermal Efficiency of the Solar Heat Collector and Drying efficiency of SAMD}

The collector efficiency of SAMD for no-load test was calculated and the efficiency was obtained as $\quad 25.84 \%$. Similarly, Struckmann(2008) stated that typical flat-plate collector efficiency needs to be between $25 \%$ and $45 \%$.

The drying efficiency of the SAMD before installing the heater was calculated as $9.05 \%$ for bitter gourd, $7.71 \%$ for jackfruit, and $11.31 \%$ for mushroom. Brenndorfer et al. (1987), suggested that the typical value of drying efficiency should be between 10 - 15\% for natural convection solar dryer. Less drying efficiencies were achieved by SAMD due to the low thermal efficiency of the solar collector and heat losses from the drying chamber door. The drying efficiencies for SAMD after installing the DC air heater were increased and calculated to be $12.85 \%$ for bitter gourd, $12.35 \%$ for jackfruit, and $13.15 \%$ for mushroom.

\section{Colour of Dried Products}

The colour of the SAMD dried products and sun-dried products were measured by colourimeter (Konica Minolta, CR 400) and International Commission on Illumination (CIE) Lightness $\left(L^{*}\right)$ values are indicated in Table 3. Visual estimation of SAMD dried products and sun-dried products are shown in Plate 1.

Table 3: Lightness $\left(L^{*}\right)$ values for each crop

\begin{tabular}{llll}
\hline \multirow{2}{*}{ Source } & \multicolumn{3}{c}{ L*Value $^{*}$} \\
\cline { 2 - 4 } & $\begin{array}{l}\text { Bitter } \\
\text { gourd }\end{array}$ & Jackfruit & Mushroom \\
\hline $\mathrm{T}_{1}$ & $32.367^{\mathrm{c}}$ & 52.090 & $68.243^{\mathrm{a}}$ \\
$\mathrm{T}_{2}$ & $59.117^{\mathrm{a}}$ & 64.020 & $48.093^{\mathrm{b}}$ \\
$\mathrm{T}_{3}$ & $48.093^{\mathrm{b}}$ & 68.243 & $46.413^{\mathrm{b}}$ \\
\hline
\end{tabular}

$T_{1}-$ Sun drying, $T_{2}-S A M D$ without DC air heater, $T_{3}$ $S A M D$ with $D C$ air heater, *Significant difference at $p \leq 0.05$, Means in the same columns followed by different letters are significantly different at $p \leq 0.05$ according to LSD.

Methods of drying were significantly affected on colour of bitter gourd and mushroom (white colour products). The significantly highest $L^{*}$ values for biter gourd were achieved by SAMD without DC air heater than SAMD with DC air heater and solar drying, respectively. In mushroom, it was significantly highest in sun drying than SAMD products at $p \leq 0.05$. These changes may be due to the nature of each agro- 
products. However, almost same colour variations were recognized in visual observations (Plate 3).

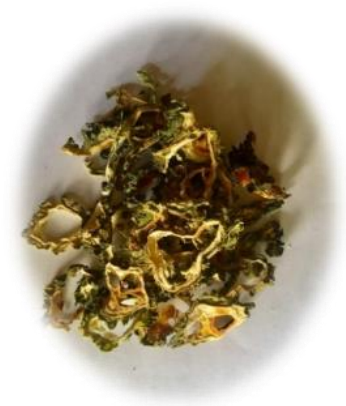

a. Sun-dried bitter gourd

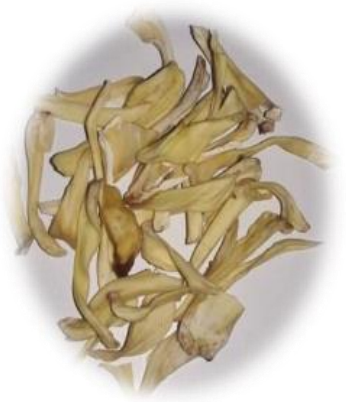

c. Sun-dried jackfruit

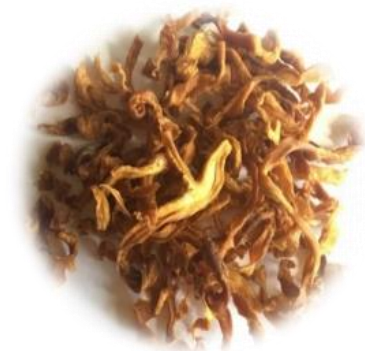

e. Sun-dried mushroom

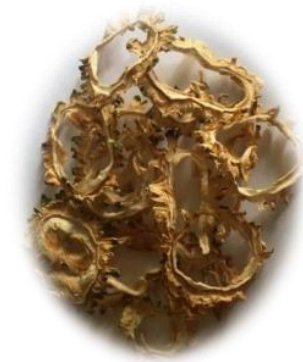

b. SAMD dried bitter gourd

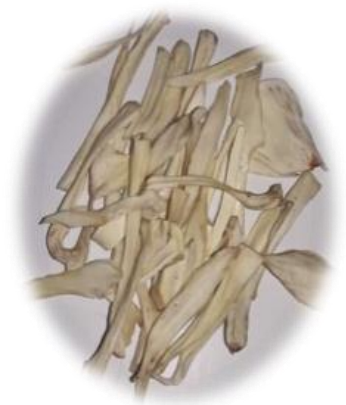

d. SAMD dried jackfruit

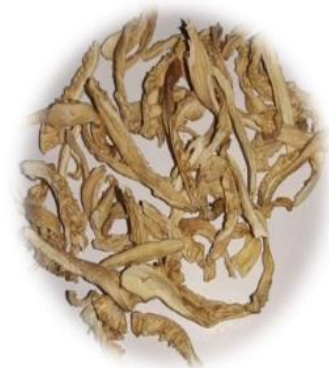

f. SAMD dried mushroom

Plate 3. Plates of sun-dried products and SAMD dried products

\section{Conclusions}

The drying efficiency of improved SAMD was higher than other methods. Further, favorable colour could be achieved by the modified SAMD. Therefore, the solar assisted multi-crop dryer designed in the present experiment can recommend for small scale farmers in Sri Lanka for drying agro-products. However, further improvements are required to increase solar thermal efficiency in future studies.

Conflicts of interest: The authors have no conflicts of interest regarding this publication.

\section{References}

Agrawal A, Sarviya R (2014) A review of research and development work on solar dryers with heat storage. Int. J. Sustain. Energy 35(6):583-605.

Brenndorfer B, Kennedy L, Oswin B C O, Trim D S, Mrema, G C, Wereko-Brommy C (1987) Solar Dryers-Their Role in Post-Harvest Processing ( $2^{\text {nd }}$ ed.), The Commonwealth Secretariat, London.

Eltief S, Ruslan M, Yatim B (2007) Drying chamber performance of $\mathrm{V}$-groove forced convective solar dryer. Desalination 209(13):151-155.

Forson F K, Nazha M A A, Akuffo F O and Rajakaruna H (2007) Design of Mixed-Mode Natural Convection Solar Crop Dryers: Application of Principles and Rules of Thumb. Renew. Energ. 32(14): 2306-2319.

Hernandez J A, Pavon G, Garcia M A (2000). Analytical solution of mass transfer equation considering shrinkage for modeling food-drying kinetics. J Food Eng 45(1): 1-10. 
Mercer D G (2007) An intermediate course in food dehydration and drying. Department of Food Science, University of Guelph, Ontario, Canada. Available from <elearning.iufost.org /sites/default/default/files/Intermediate-Out line-1.pdf>. [30 March 2019]

Leon A M, Kumar S, Bhattaharya S C (2002) A comprehensive procedure for performance evaluation of solar food dryers. Renew. Sust. Energ. Rev. 6: 367-393.

PV Watts (2019) PV Watts Calculator. Alliance for Sustainable Energy. Available from, <pvwatts.nrel.gov/> [12 March 2019.]

Raju R V S, Reddy R M, Reddy E S (2013) Design and Fabrication of Efficient Solar Dryer. J. Eng. Res. 3(6): 1445-1458.

Saxena A, Goel V (2013) Solar Air Heaters with Thermal Heat Storages, Chinese Journal of Engineering.

Scanlin D, (1997) The Design, Construction and Use of an Indirect, Through-pass, Solar Food Dryer, Home Power Magazine. 57: 62-72.
SolarFlex (2013) Drying Fruits and Vegetables with the Solarflex Dryer. Available from http://w.w.w.postharvest.org/Drying\%20Fruit s\%20and\%20Vegetables\%20with\%20the\%20S olarFlex\%20Dryer.pdf. [15 March 2019]

Struckmann F (2008) Analysis of a Flat-plate Solar Collector, Project Report: 2008 MVK 160, Heat and Mass Transport. Lund University, Lund, Sweden.

Tibebu T B (2015) Design, construction and evaluation of performance of solar dryer for drying fruit. Department of Agricultural Engineering, Kwame Nkrumah University of Science and Technology, Ghana.

Tiwari A (2016) A review on solar drying of agricultural produce. J Food Process Technol, $7(9)$.

Weiss W, Buchinger J (2002) Solar Drying. Austrian Development Cooperation, Austria. Available from http://t.aee-intec.at/0uploads /dateien553.pdf. [17 February 2019]. 